\title{
Pintura de Historia y Estampa de Actualidad: La escena de tema bélico
}

\author{
M. ${ }^{a}$ Dolores Bastida de la Calle *
}

No sería aventurado afirmar que la aparición del grabado cambió la imagen que el arte transmitía sobre la guerra. Durante siglos, la exaltación épica de la victoria, la conquista, la gloria del soberano, fueron motivo único en la representación plástica de la escena bélica, desde las estelas y frisos egipcios o asirios hasta los grandes óleos palaciegos en los estados de la Europa moderna ${ }^{1}$. Las paredes del Salón de Reinos del Buen Retiro fueron cubiertas con lienzos de Carducho, Castelo y Pereda que plasmaban las victorias de los ejércitos de Felipe IV. El Imperial War Museum de Londres es un inmenso registro pictórico de las glorias imperiales británicas ${ }^{2}$. En Versalles y en el Louvre, cuadros de David, Lejeune y Gros todavía nos recuerdan las convulsiones de la Europa de Napoleón.

En Gros, en particular, culmina el tono grandioso y épico de la pintura napoleónica. Su exaltación de lo heroico discurre desde las colosales figuras del primer plano en la batalla de Aboukir, hasta la figura de Bonaparte en el asalto al puente de Arcola o el retrato ecuestre de Murat. En la batalla de Nazareth del Museo de Nantes, una composición deliberadamente romántica que en modo alguno corresponde a una descripción veraz de un episodio bélico ${ }^{3}$, Gros utilizó el lenguaje heroico para el personaje dramático de Junot, la impasible carga de los dragones, y la violencia de los caballeros y caballos abatidos. $Y$ aunque alejados de las frías convenciones de la escuela neoclásica, el elemento conmovedor

* Dpto. H. ${ }^{a}$ del Arte. UNED.

La guerra y la paz. Barcelona, Vicens-Vives, 1964, págs. 52.

En 1939, el gobierno británico creó un "War Artist's Advisory Commitee" para extender ese registro a todos los aspectos de la guerra recién iniciada. Véase NEWTON, Erice, War through artist's eyes. Printings and drawings by British War artists. Londres, John Murray, 1945, pág. 7.

3 KEEGAN, J. and DARRACOTT, J., The Nature of War. Nueva York, Holt, Rinehart and Winston, 1981, pág. 106. 
de los heridos de Eylau o el toque de horror de los apestados de Jafa son tan sólo acentos de "pathos" romántico; es la figura soberbia del emperador y "su compasión por los muertos y moribundos, no la desgracia de éstos", lo que se busca enfatizar ${ }^{4}$. De hecho, en el boceto inicial del episodio de Jaffa Gros mostraba a Bonaparte con un apestado en brazos, en una máxima exageración sensiblera de su heroísmo ${ }^{5}$. Se ha llegado a señalar, por otra parte, que en ocasiones Gros "dibujó a sus héroes en actitudes de vaso griego" ${ }^{6}$, una polémica influencia de los ideales clásicos de su maestro David.

El grabado, cuya difusión era mucho más pluralista que la pintura, permitió la primera expresión de un vigoroso sentimiento opuesto al sofisma pictórico militar. Ya en el siglo XVII, la serie de aguafuertes de Jacques Callot, Grandes Miserias de la Guerra, mostró a extensas capas de la población europea la brutalidad, los incendios, las torturas, los excesos salvajes de la lucha real entre milicias. Callot era un moralista y, como tal, su tendencia antiheroica implicaba el mostrar la verdad desnuda de la guerra y su devastación ${ }^{7}$. Otro grabador, el florentino Stéfano della Bella, siguiendo las huellas de Callot, retrató en una serie de estampas aspectos anecdóticos de las campañas bélicas de su tiempo ${ }^{8}$. Naturalmente, la condena de la locura de la guerra llegó a su máxima expresión a comienzos del siglo xIX, en los aguafuertes de Goya sobre los grotescos horrores de las guerras napoleónicas en España.

Una descripción veraz de la temática bélica parecería exigir del artista cierta familiaridad con las peculiaridades de la vida militar. Durante largo tiempo, sin embargo, tal familiaridad no condujo a una descripción de la verdad de la guerra. En la escuela realista de pintores de batalla del siglo xVII, de la que Jacques Courtois, el Borgonón, soldado durante tres años en el ejército español de Milán, es considerado el intérprete más notable ${ }^{9}$, se mantiene la visión grandiosa de los combates, con inverosímiles vistas a vuelo de pájaro y vastas panorámicas del campo de batalla. Y aún a comienzos del siglo xix, como se ha recordado, perdura el sofisma pic-

Honour, Hugh, El Romanticismo. Madrid. Alianza, 1989, pág. 50.

AleXANDRE, Arsene. Histoire de la peinture militaire en France. Paris. Henri Laurens, 1889 pág. 142

Falrchild Zogbaum, Rufus. "War and the Artist", Scribner's Magazine, Vol. 57. enero (1915), págs. 16-35

SAXLS, F., "The battle scene without a hero". Journal of the Warbug and Courtauld Instrtutes, (1939-40), págs. 70-87.

Batallas. Pinturas de los siglos xvir al xix en los Museos de Florencia. Madrid. Ministerio de Cultura, 1990, pág. 20.

Op. cit., pág. 22 
tórico militar en artistas que habian conocido la experiencia de las campañas napoleónicas, como Gros, o Lejeune, él mismo un general. Se hace, por tanto, significativo observar que, tan sólo medio siglo más tarde, el detallismo positivista de escena bélica surge con toda su fuerza en la generación de Meissonier ${ }^{10}$, de Neuville, Detaille, artistas que pintaron una guerra, la francoprusiana, que vivieron como oficiales. En el caso de Detaille, su doble faceta de patriota y artista le llevaba, en el frente, al uso indistinto de lápiz y fusil ${ }^{11}$.

Es asi interesante observar que el lenguaje plástico del grabado narrativo marcó a esos artistas. Coetáneos suyos fueron los pintores de la escuela impresionista, sobre los que, como ha probado Joel Isaacson, tuvieron una influencia determinante, tanto iconográficamente como, en menor medida, formalmente, las imágenes de la abundante ilustración periodística del período 1840-1870 ${ }^{12}$. Una variante de esa ilustración, la estampa de actualidad bélica, realizada por un artista reportero enviado al frente para reiratar las acciones de una campaña, se caracterizó por una estética positivista que enfatizaba la captación del detalle in situ y la inmediatez, al modo de la naciente y coetánea fotografía ${ }^{13}$. El grabado de actualidad ofreció a la audiencia de las revistas ilustradas - una influyente clase media, ávida de información - el retrato veraz de su presente histórico.

Como los artistas reporteros, los pintores de la guerra franco-prusiana hicieron uso de un lenguaje naturalista, con una iconografía de carácter, a menudo, antiheroico. De Neuville fue el pintor de la derrota frente a los prusianos; Detaille, por su parte, llegó a pintar el envés del heroísmo: el robo y despojo de heridos y muertos tras una batalla. Estos artistas huyeron de lo épico, enfatizando la anécdota y el episodio. En De Neuville, en particular, "la filosofía de la obra es más general, a medida que el tema es más restringido" " n'est intelligible et intéressant qu'à la condition d'être un simple épisode de la vie militaire». Un extremado interés documental y cuasifotográfico por los tipos individuales, y una búsqueda continua de croquis e «instan-

\footnotetext{
10 Constance Cain, Hungerford, "Meissunier's Siège de Paris and Ruines des Tuilleries". Gazette des Beaux-Arts, núm. 1462 (1990), págs. 201-212.

"MACHRAY, Robert, "A group of Battle-Painters and War Artists", Windsor Magazine, Vol. XII, octubre (1900), págs. 260-274

ISAACSON, Joel, "Impressionism and Journalistic Illustration», Arts., núm. 56, junio (1982), págs. 95-115.

13 BAStidA, M. Dolores, "El Arte de la llustración de Noticia", Espacio, Tiempo y Forma, Serie VII, núm. 5 (1992), págs. 385-394.

'7 Alexandre, Arsène, Op. cit, pág. 296.
} 
táneas" del natural, fueron rasgos comunes a los pintores de esta escuela. De Detaille se dijo que su ojo era un objetivo que fotografiaba instantaneamente las cosas ${ }^{15}$.

Un rasgo esencial, no obstante, les diferenció del corresponsal artístico de guerra. El corresponsal fijaba imágenes de incidentes "del momento", en una campaña; su trabajo tenía así una urgencia de la que carecía el pintor, quien plasmaba en sus lienzos incidentes que, a lo sumo, él mismo había contemplado en el pasado ${ }^{16}$. Es verdad, sin embargo, que muchos artistas reporteros, una vez abandonada su actividad periodística, revivieron en óleos, aguafuertes, o litografías, escenas de guerra de las que habian sido testigos gráficos en algún tiempo. Hay ejemplos abundantes de esa doble faceta, como los de William Simpson en la campaña de Crimea, Edwin Forbes, reportero del semanario americano Frank Leslie's Illustrated Newspaper en la guerra de Secesión Americana, o Caton Woodville, quien, tras las campañas serbia de 1878 y egipcia de 1882 , como artista del londinense IIlustrated London News, pintó grandes lienzos de tema militar, de notable éxito en exposiciones de la Real Academia de Londres.

Caton Woodville volvió a la revista ilustrada durante la Primera Guerra Mundial, colaborando como dibujante de estudio en el Illustrated London News. Hubo también pintores de Historia que, sin haber sido nunca corresponsales artísticos, trabajaron en la prensa gráfica como dibujantes de estudio. Este fue el caso de Ricardo Balaca en La llustración Española y Americana, y Felix Regamey en el London News, durante la guerra carlista de 1872-1876, un conflicto que interesa aqui por coincidir con un momento de máximo esplendor de la ilustración de actualidad. Otros pintores de Historia como Jean Paul Laurens y Pablo López Elorga colaboraron brevemente en esa guerra, enviando sketches desde el frente. La revista francesa L'illustration publicó dos dibujos sobre croquis de Laurens en mayo de 1872; López Elorga colaboró en Le Monde Illustré con dos croquis que, acabados por Daniel Vierge, aparecieron en la revista el 8 de junio de 1873.

La diferencia entre el dibujo de actualidad y la pintura clásica de tema bélico, se puede contrastar sobre una notoria batalla del conflicto carlista.

\section{Ibidem. pág. 310 .}

16 El corresponsal de guerra, que habia de enviar sus croquis o dibujos en un plazo de 24 o 48 horas, no disponia, ciertamente, de ese "lapso de años" que, como señala $V$. Bozal, en su detallado análisis sobre las escenas de guerra de Goya, "transcurre desde los acontecimientos iniciales hasta que (el artista) pinta los cuadros". Véase Bozal, V., Imagen de Goya. Barcelona, Lumen, 1983, pág. 233. 
El 7 de julio de 1875, en las cercanías de Treviño, el Regimiento de Lanceros del Rey n. 1 cargó sobre el tercer batallón de Navarra, mandado por José Pérula, el escribano de Corella, en una acción decisiva para el ejército liberal. La Ilustración Española y Americana registró el incidente en un dibujo de Daniel Perea sobre croquis de un testigo presencial (fig. 1). En la revista el observador está situado muy próximo a los carlistas derrotados y caídos, y la estampa, que no atribuye rasgos heroicos a los jinetes vencedores, transpira toda la confusión de un hecho de armas real. Como en los lienzos de Aniello Falcone, creador de la batalla sin héroe, la estampa sólo representa soldados anónimos, figuras carentes de importancia narrativa. Aunque Falcone estuvo siempre interesado por tales figuras, posiblemente nunca presenció una batalla ${ }^{17}$. Aquí, por el contrario, la ausencia de "personajes» en la estampa sería consecuencia de que la realidad inmediata que captó el reportero, lo que tuvo ante sus ojos, fue un episodio mínimo del combate.

Aunque la batalla de Treviño fue una acción menor, sólo documentada en La llustración Española y Americana, su carácter de carga de caballería capturó la imaginación de pintores de Historia españoles. Ricardo Balaca la llevó al lienzo en 1881, Eduardo Banda y Victor Morelli ${ }^{18}$ en 1895 y 1897, respectivamente. Fue López Elorga, sin embargo, quien primero pintó el tema en 1877, tras un dibujo, "La carga de caballería dada por el coronel Contreras en Treviño", presentado en la Exposición Nacional de 1876; aunque estática, la composición del óleo, que se encuentra en la Academia de Caballería de Valladolid, subraya las figuras heroicas del coronel del Regimiento, Juan Contreras Martínez, y del capitán Torres Cañamás, muerto en la acción (fig. 2). En el inmenso cuadro de Morelli, de siete metros de largo, los lanceros parecen emerger, abriéndose, de un punto de fuga en el centro del cuadro (fig. 3), una representación que captura el dinamismo y el impacto de una carga de caballería, en una exaltación iconográfica usual en la pintura militar oficial del siglo XIX; el punto de vista es semejante al adoptado por Elizabeth Southerden, artista célebre en el mundo militar británico del siglo xIx, en "Scotland For ever», una plasmación de la carga del Regimiento Scots Greys en Waterloo

\footnotetext{
17 Como de Detaille, se ha dicho de Falcone que fue pintor de noche y héroe de dia, participando en la revolución napolitana de 1647 con la "Compagni della Morte"; documentos de la época prueba, sin embargo, que la leyenda de la Compañía es falsa. Véase SAXLS, F., Op. cit.

Eduardo Banda y Pineda estudió paisaje y composición en Madrid y obtuvo mención honorífica en las Exposiciones Nacionales de 1892 y $\$ 895$. El Teniente General Victor Morelli y Sánchez Gil, que estudió arte en La Coruña. Barcelona, Madrid y Roma, es asimismo autor de un cuadro sobre la "Batalla de Castellfollit", que tuvo lugar el 14 de marzo de 1874
} 


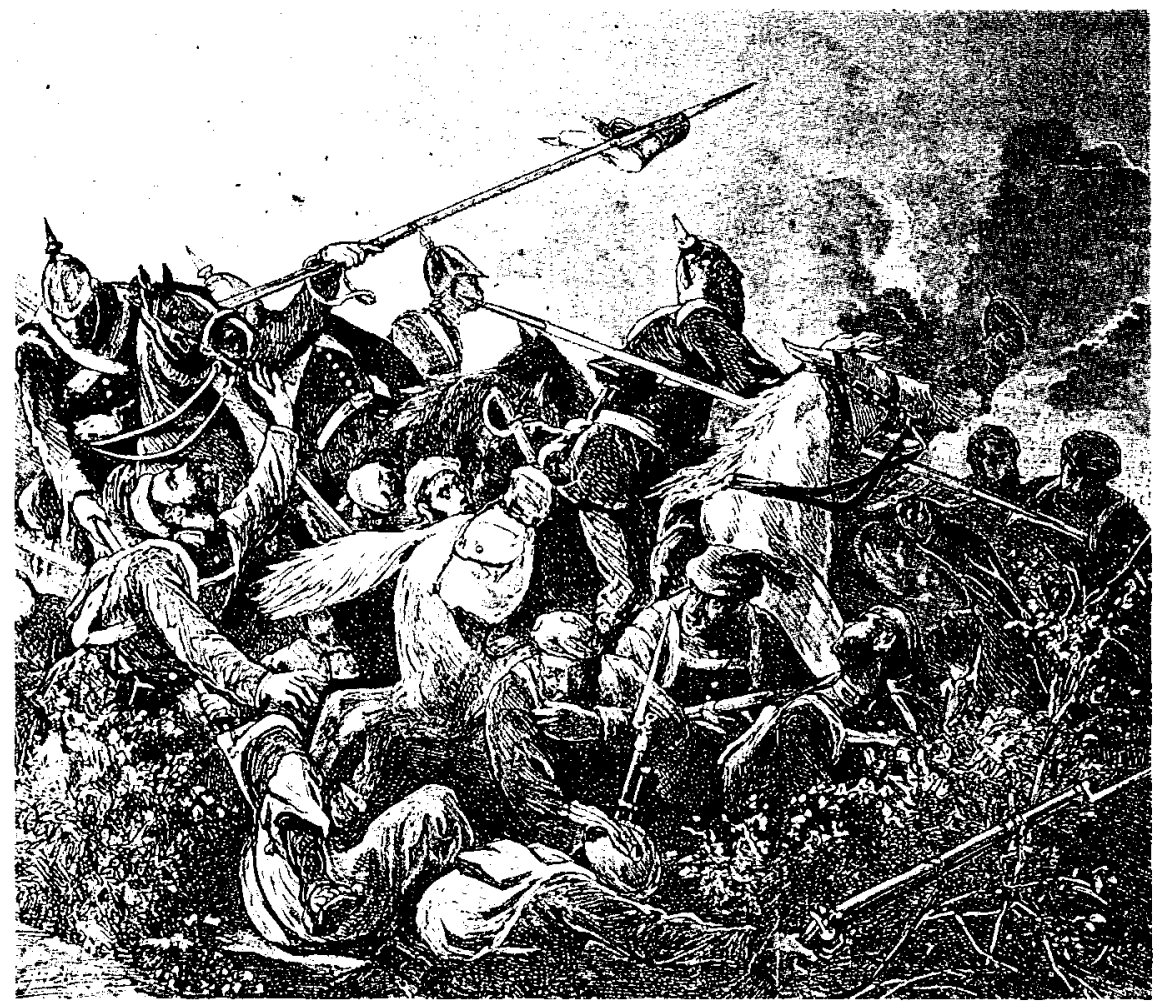

Fig. 1. PEREA, Daniel, Carga heroica de 98 lanceros del rey, al mando del coronel Contreras, en la acción del Condado de Treviño, el 7 del actual. La llustración Española y Americana, 15 de julio de 1875.

(fig. 4). Por su parte, el óleo de Banda (fig. 5) recuerda a las Batallas de Tetuán y Wad Ras de Fortuny, composiciones en horizontal con profusión de figuras pequeñas, aunque Banda buscó enfatizar detalles en armas y uniformes, al modo positivista.

Pero los rasgos característicos de la pintura de Historia también asoman a veces en las estampas de la prensa gráfica. Es, en particular, en los hechos singulares de un conflicto donde esas reminiscencias del género se manifiestan más nítidamente. Un caso excepcional en la guerra carlista fue la muerte del general Concha, ocurrida al atardecer del $27 \mathrm{de}$ junio de 1874, e ilustrada de diverso modo en La llustración Española y Americana, Le Monde Illustré, The Illustrated London News, el Harper's Weekly, de Nueva York, y la Illustraziones Universale, de Milán. Crónicas 


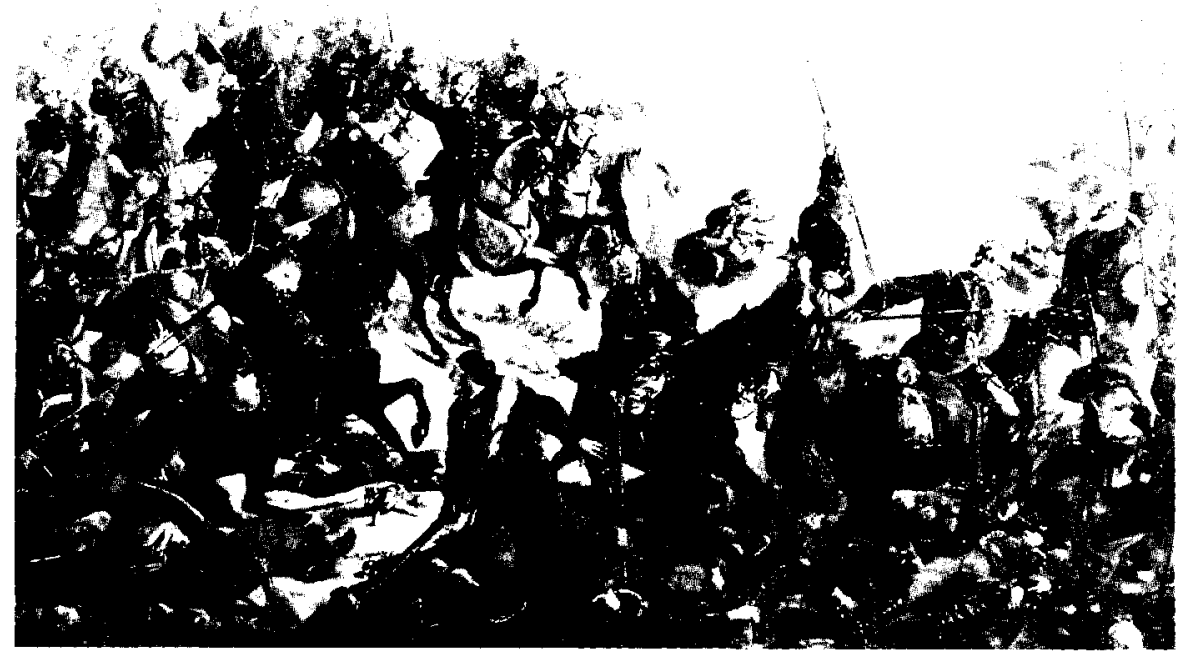

Fig. 2. Lopez Elorga, J. Pablo, La carga de caballeria dada por el coronel Contreras en Treviño. 1877. Academia de Caballería. Valladolid.

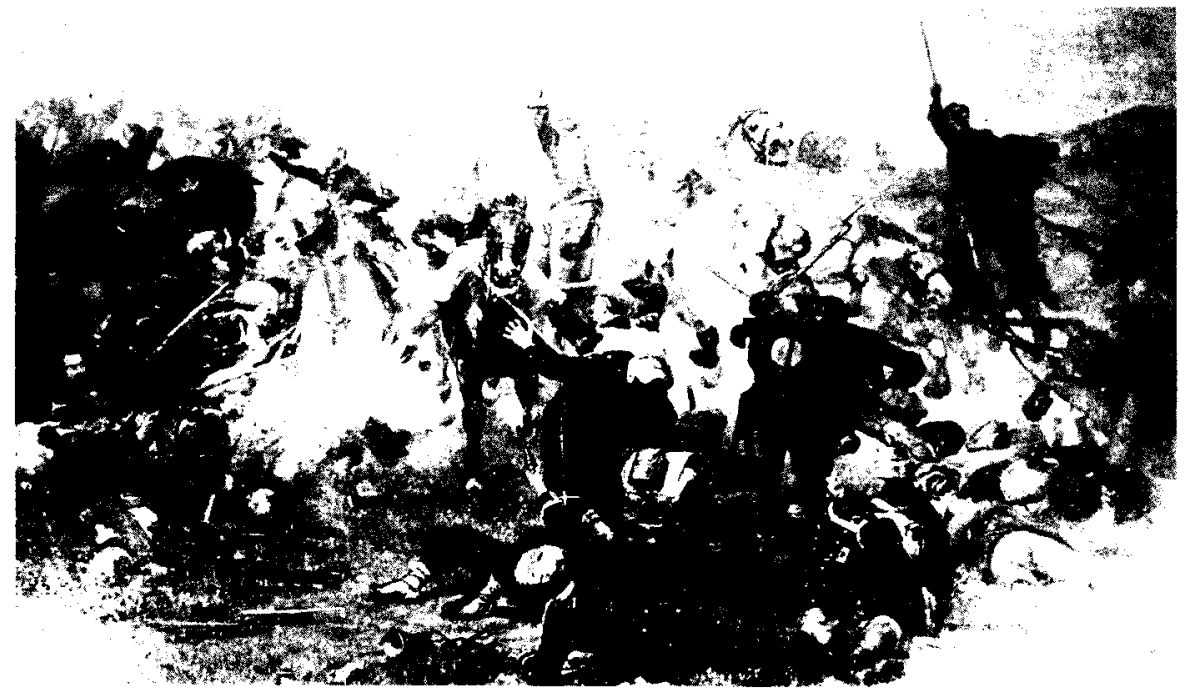

Fig. 3. Morelli, Victor, Batalla de Treviño, 1897. Academia de Caballeria, Valladolid. 
de la prensa de la época (El Imparcial) del 30 de junio de 1874, Le Monde IIlustré del 11 de julio, el Illustrated London News del 18 de julio) permiten reconstruir algunos aspectos esenciales del suceso: en algún momento de la larga batalla descargó una fuerte tormenta; Concha se había ya retirado de la primera línea cuando fue alcanzado por una bala; la muerte le sobrevino en el momento en que su ordenanza, Ricardo Tordesillas, le ayudaba a montar en su caballo.

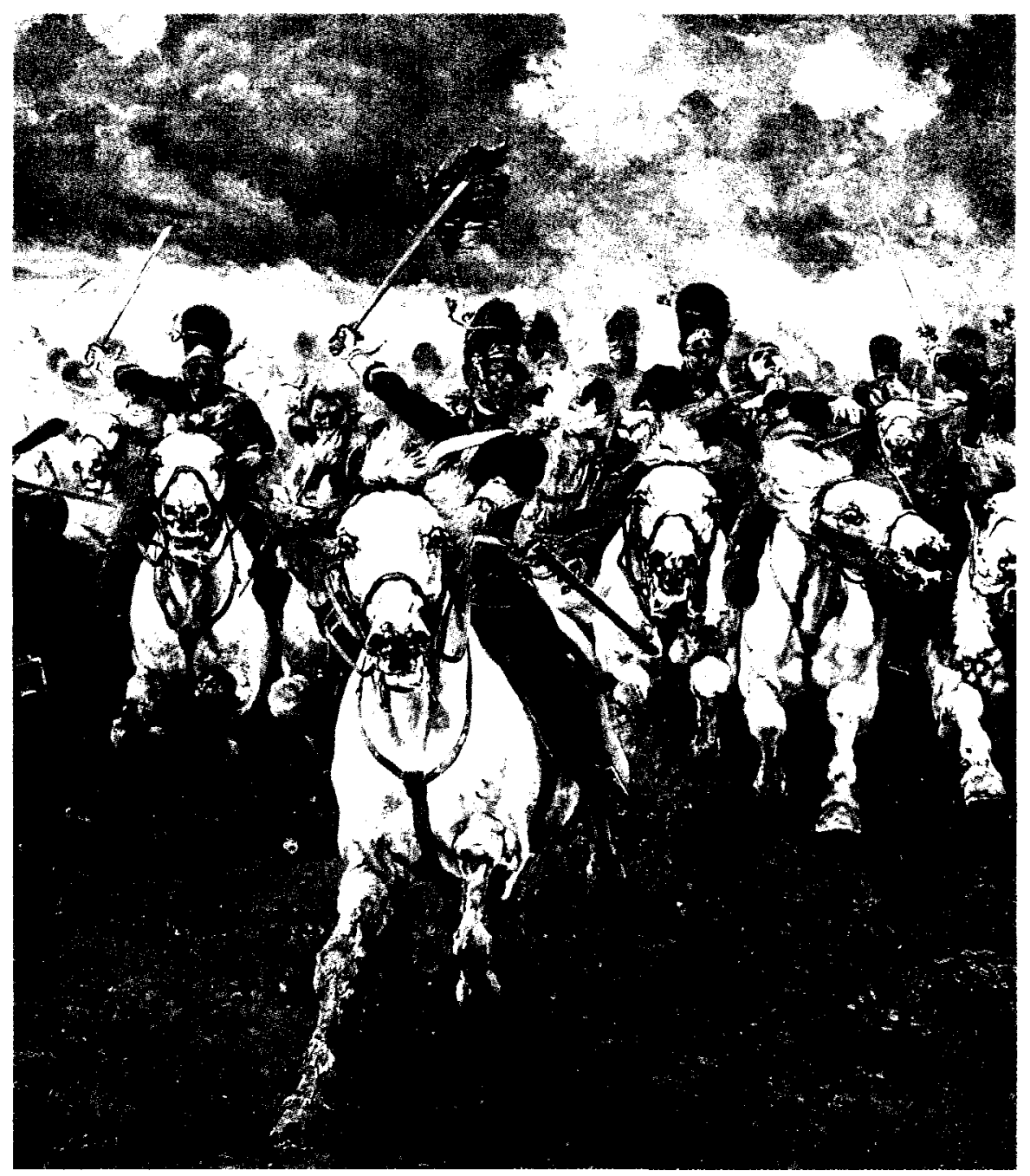

Fig. 4. Southerden, Elizabeth, Scotland for ever, 1881. City Art Gallery, Leeds. 


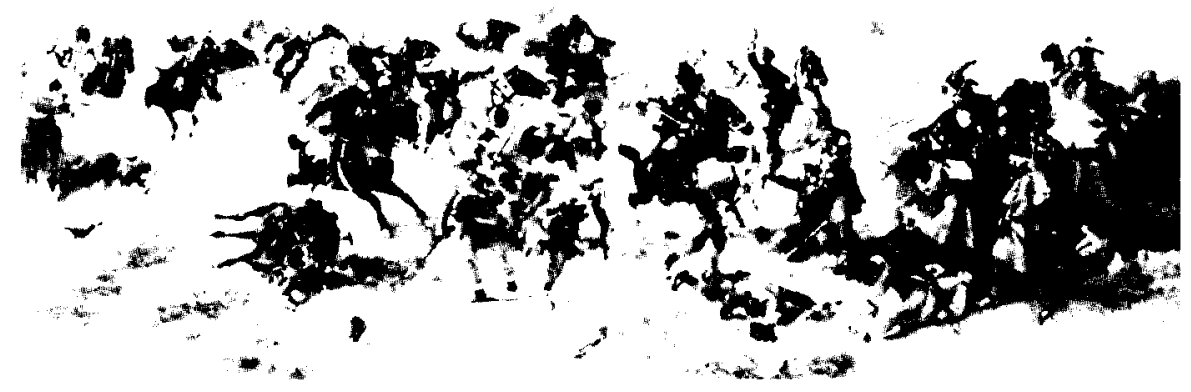

Fig. 5. Banda, Eduardo. Batalla de Treviño, 1895. Museo del Ejercito, Madrid

El grabado de La llustración Española y Americana, "Gloriosa muerte del Sr. Marqués del Duero", julio 8, 1874 (fig. 6), un simple croquis según la leyenda de la revista, tiene el valor documental y la veracidad de una crónica periodística, en contraste notable con las estampas de Le Monde Illustré y el Harper's (fig. 7), que acuden a una variedad de recursos para intensificar el acento trágico del tema. Las estampas de estos dos semanarios, aunque basadas en informes enviados por testigos, son dibujos realizados en estudio (por Fernando Miranda y Daniel Vierge, respectivamente); su iconografía, notablemente teatral, sitúa la muerte de Concha en medio de violentos enfrentamientos entre carlistas y liberales, y en el marco de una tormenta furiosa. El dibujo de La llustración Española y Americana, enteramente opuesto, tiene varios rasgos en común con el del Illustrated London News. Ambos son croquis de testigo presencial, del oficial D.E.J. el primero, del teniente Linares del Ejército liberal el segundo; de hecho, en la estampa española no hay siquiera intervención de dibujante de estudio, intervención que hubiera sido reconocida de haberse producido, según práctica habitual de la revista. Por otra parte, las imágenes de La llustración Española y Americana y del Illustrated London News omiten cualquier escenificación teatral y sitúan la muerte de Concha a cierta distancia de la primera línea de combate, sin señal alguna de tormenta (fig. 8).

Es claro que Miranda y Vierge buscaron enfatizar la intensidad dramática de la escena fusionando planos espaciales y temporales diferentes, un procedimiento ajeno al usual carácter de instantánea fotográfica del 


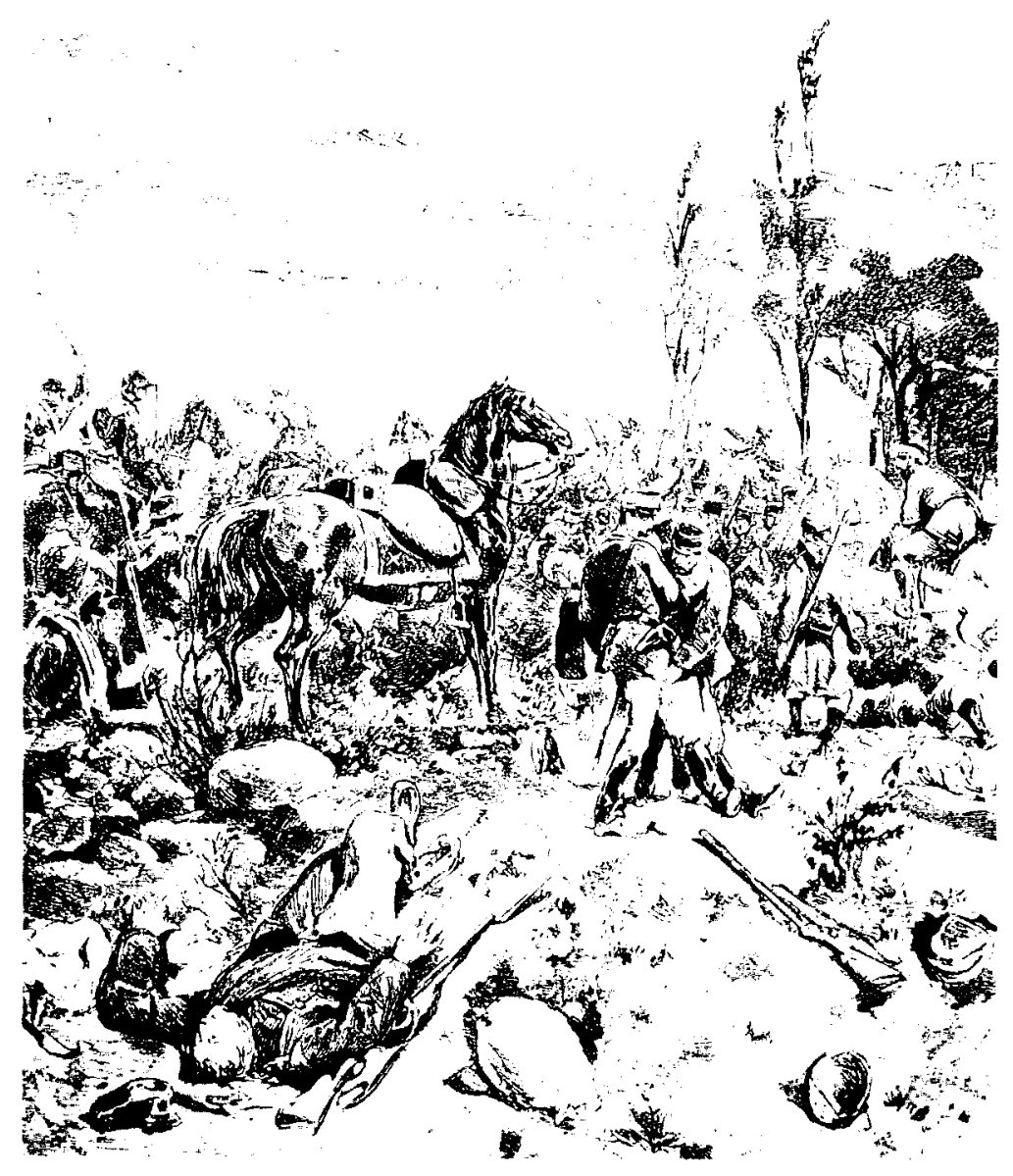

Fig. 6. Gloriosa muerte del Sr. Marqués del Duero. La llustración Es. pañola y Americana, 8 de julio de 1874.

dibujo de noticia pero no a la composición pictórica narrativa. Ese carácter de instantaneidad permite explicar asimismo la peculiar iconografía de la estampa española, en la que el general en jefe del Ejército del Norte, 


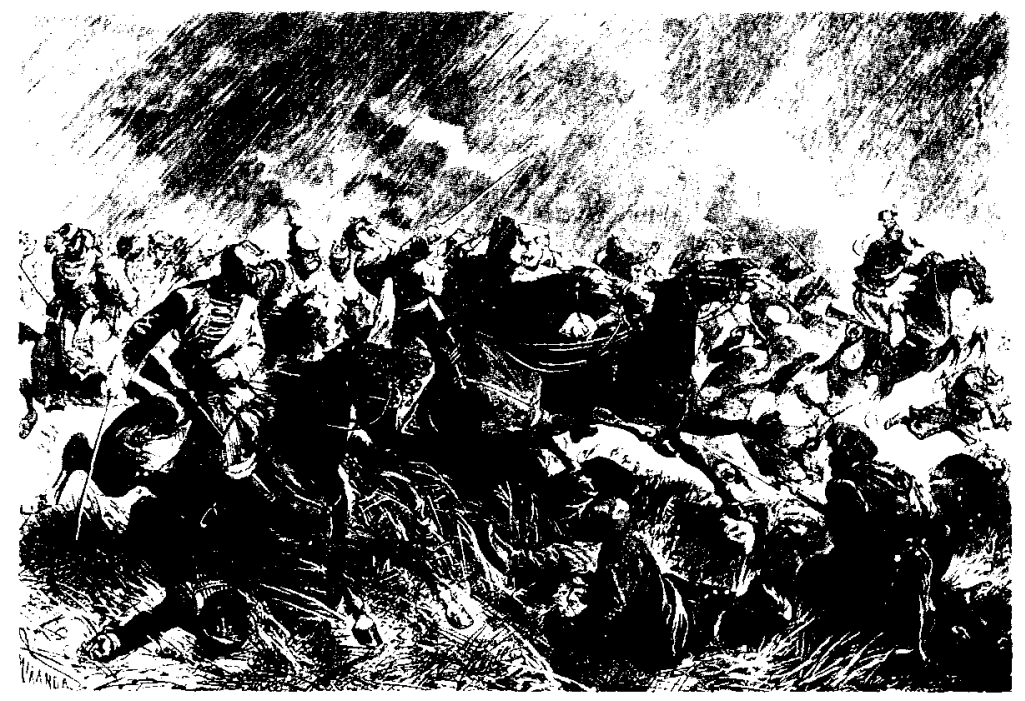

Fig. 7. Miranda, Fernando, The death of Marshal Concha. Harper's Weekly, 8 de agosto de 1874

moribundo, aparece prácticamente solo, algo paradójico en apariencia, en una primera impresión. Los datos históricos, sin embargo, confirman la veracidad de la escena considerada como una instantánea. Oyarzun ${ }^{19}$ señala que el general retornaba de las proximidades de la primera línea, "con los que le acompañaban, a donde estaban los caballos. Allí, ya fuera de peligro, habianse colocado los ordenanzas, separados entre sí, según el terreno, y el del General en Jefe, aunque inmediato a los otros, ..."no a su vista"...». El general Concha pidió el caballo a su ordenanza, Ricardo, y "en el momento de cruzar la pierna por la grupa, una perdida bala de fusil, le atravesó el pecho... Las voces de Ricardo atrajeron a los que estaban inmediatos", entre ellos el teniente de Húsares Montero, el capitán Grau, y otros ayudantes, que colocaron al moribundo a la grupa de una de sus monturas.

La estampa publicada en la Illustrazione Universale, "Spagna.-Morte del Generale Concha a Muro presso Estella" (fig. 9), guarda cierta semejanza iconográfica con la del lllustrated London News. Podría pensarse que el dibujante italiano Cenni hizo una reconstrucción del hecho basada

10. Oyarzun, Roman, Historia del Carlismo. Madrid, Pueyo, 1965, pág. 303. 


\section{THE ILLUSTRATED CONDON A NEYS.

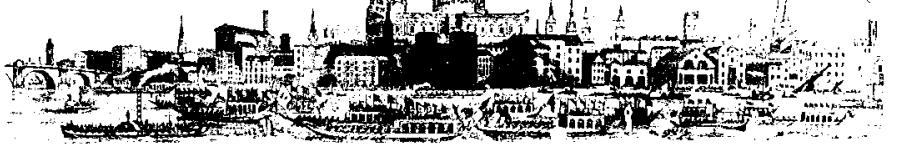

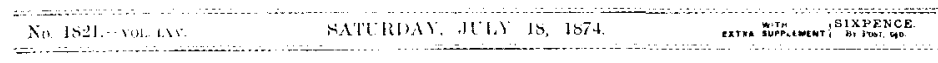

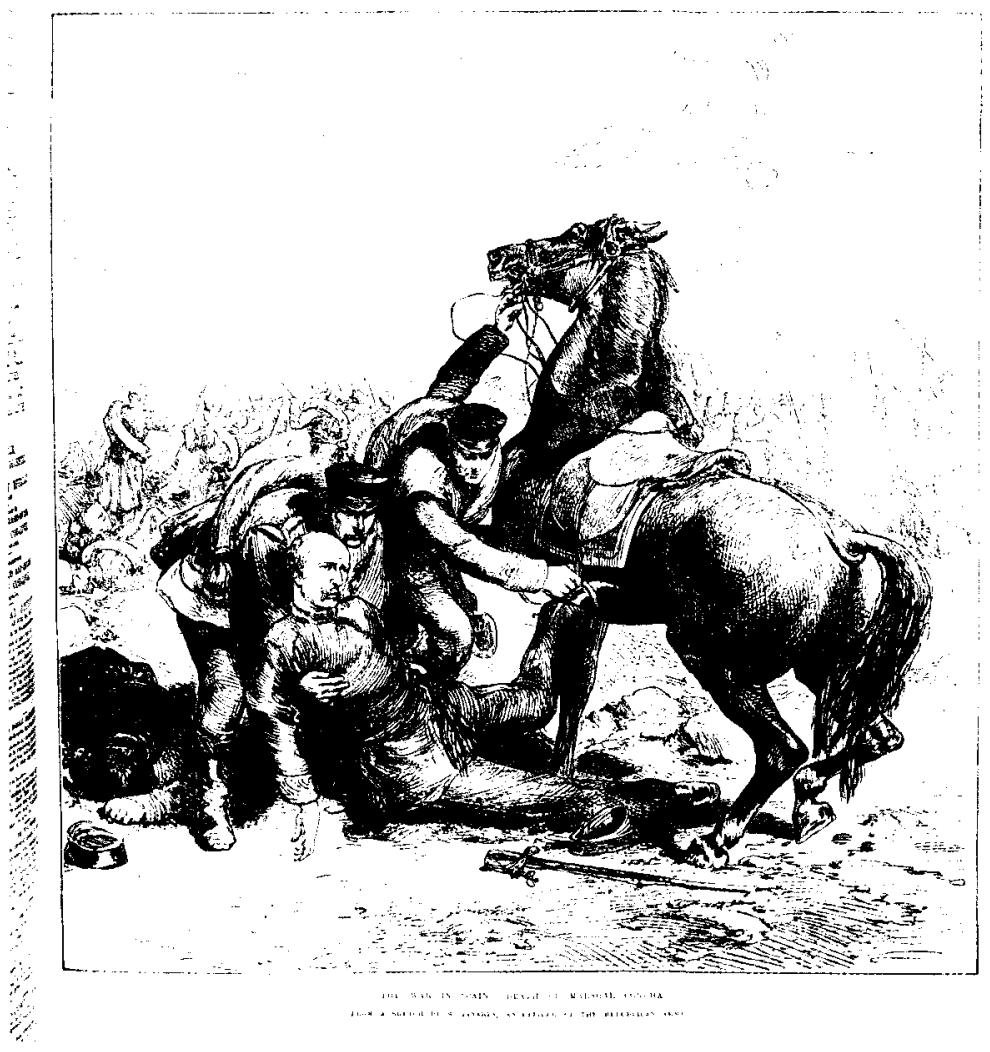

Fig. 8. Death of Marshal Concha. The Illustrated London News, 18 de julio de 1874. 
en el grabado del semanario inglés, aparecido 15 días antes del italiano. Por otra parte, la calidad y fidelidad del dibujo de la lllustrazione son tan pobres que el general, anciano entonces, aparece como un joven. La composición horizontal, que recuerda un friso, desenfoca el punto central de la escena con los caballos distorsionados que alargan la imagen hacia la derecha.

La concentración iconográfica es máxima, por el contrario, en la revista inglesa. Nótese que, en su descripción del grupo que rodea a Concha, el artista se inspira en una "deposición", con la tradicional colocación de las figuras que provoca esa sensación de desfallecimiento del cuerpo de Cristo al descender de la Cruz. La estampa, sin embargo, rompe con todo tipo de antiguas convenciones al trasladar el recurso del homenaje emocional de la religión al nacionalismo. La composición enlaza con la del pintor norteamericano Benjamín West, afincado en Inglaterra. En 1770, su cuadro "La Muerte del General Wolfe" (fig. 10), sobre un episodio de la toma de Quebec en 1759, marcó un paso decisivo en la nueva manera de entender la pintura de historia en Gran Bretaña. La influencia de este óleo se deja ver en una variedad de pintores anglo-sajones, como J. S. Copley o John Trumbull (The Battle of Bunker's Hill), oficial del ejército continental en la guerra de Independencia americana, que posteriormente estudió con West en Londres. El pintor inventó una forma artística en la que renunciaba a revestir la actualidad de atuendo clásico ${ }^{20}$ a fin de

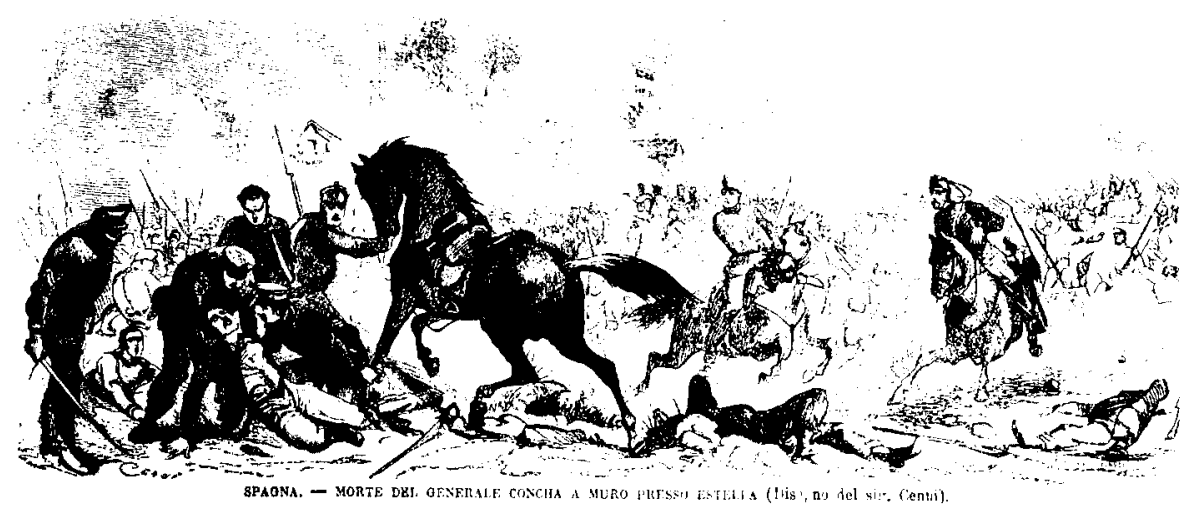

Fig. 9. CENNI, Quinto, Morte del generale Concha a Muro presso Estella. Nuova Illustrazione Universale, 2 de agosto de 1874.

20 LunA, Juan J., Pintura Británica (1500-1820), Summa Artis, Vol. XXXIII. Madrid, Espasa Calpe, 1989, pág. 475. 
relatar la historia de su tiempo en clave comprensible para el hombre común, mostrando las anécdotas históricas coetáneas a través del prisma de lo cotidiano.

Hay un tema bélico, el de los fusilamientos de prisioneros, que contradice naturalmente el sofisma pictórico militar. No es así extraño que la primera escena que recoge esa imagen para el arte'sea una plancha de las "Grandes Miserias de la Guerra», Pero en el siglo xix el tema surge con una enorme carga dramática, iniciada con el terrible "Fusilamiento del 3 de Mayo" de Goya. A lo largo de la centuria la imagen recurre una y otra vez, como en "La ejecución de Maximiliano de Habsburgo" de Manet, o el "Fusilamiento de Torrijos y sus compañeros» de Gisbert.

En la guerra carlista hay numerosos ejemplos de tales ejecuciones. documentados en los semanarios ilustrados. El I/lustrirte Zeitung de Leipzig alude repetidamente a fusilamientos realizados por los carlistas. El 4 de marzo de 1876, hablando de Estella, el semanario alemán decía "...éste fue también el escenario impío de las ejecuciones a sangre fría de desdichados prisioneros de guerra, supuestamente en venganza por ficticias atrocidades de los enemigos, en realidad con el propósito de

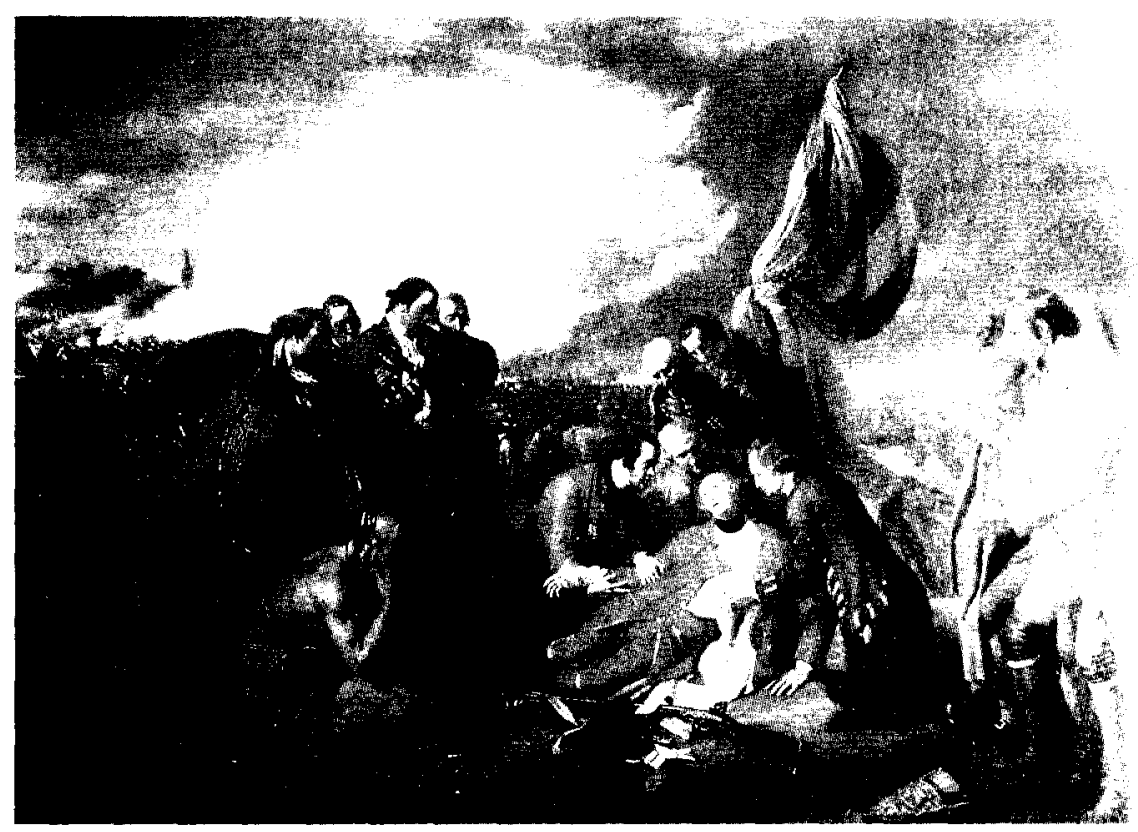

Fig. 10. WESt, Benjamin, La muerte del general Wolfe, 1770. National Galiery of Canada, Ottawa. 
difundir el terror»; y en agosto 2, 1873: «los carlistas que en nombre de Dios, la Patria y el Rey... fusilaban a sus prisioneros" ${ }^{21}$. En Le Monde Illustré del 1 de agosto de 1874, describiendo la toma de Cuenca, se habla de quema de la prefectura, apropiación de los impuestos, y fusilamientos sobre el terreno ${ }^{22}$. En esa misma fecha el Illustrated London News hace mención a 41 carlistas detenidos en Barcelona como represalia por el fusilamiento de republicanos ${ }^{23}$. Toda la prensa gráfica ofrece abundantes referencias a ejecuciones ordenadas por el cura Santa Cruz.

En la estampa de La Ilustración Española y Americana del 30 de agosto de 1874, "Fusilamientos de prisioneros de la columna Nouvilas en el cementerio de Llayés, el 17 de julio" (fig. 11), Perea describe la ejecución de prisioneros republicanos por carlistas catalanes comandados por el cabecilla Savalls ${ }^{24}$. El día 17 de julio, 75 carabineros y 110 miembros del ejército designados en una quinta, entre ellos un médico, un jefe y 12 oficiales, fueron conducidos a las inmediaciones de Llayés y fusilados en el cementerio de San Juan de las Abadesas.

Aunque bien conocida la influencia de Goya sobre Manet, la estampa de Perea está mucho más próxima a la escena del 3 de mayo. Ciertamente el lenguaje artístico de cuadro e ilustración es en algún aspecto el mismo. Ambos traslucen la oposición entre una masa desordenada de hombres con la pasión de la muerte en los rostros, y una fila de soldados en orden militar y con una disposición regular de los fusiles. Hay, sin embargo, diferencias notables entre una y otra obra.

El óleo de Goya plasma el levantamiento de un pueblo contra sus invasores y tiene el valor persistente de un símbolo, aún cuando éste se enmarca en una experiencia concreta ${ }^{25}$. La estampa de Perea, por el contrario, tiene el carácter informativo del dibujo de noticia. La estampa es la narración de un suceso del que tan sólo se representa un «instante»:

21 Illustrirte Zeitung, núm. 1704 (1876), pág. 170 y núm. 1570 (1873), pág. 82

22 Le Monde lllustré, núm. 903 (1874), pág. 70.

23 Illustrated London News, núm. 1823 (1874), pág. 98.

24 En la acción de Castellfollit, que había tenido lugar el 14 de marzo entre la columna del general Nouvillas y la facción Saval!s, quedaron prisioneros de los carlistas unos 600 soldados liberales y su jefe herido, con la inmediata rendición de la villa de Olot. En ella estaban todavía los prisioneros a mediados de julio último, cuando los carlistas decidieron el segundo ataque contra Puigcerdá, y a fin de evitar que fueran liberados entre tanto por las tropas republicanas, les ordenaron salir para Vallfogana y dispusieron que todos los pertenecientes al cuerpo de carabineros fuesen fusilados y quintados los demás, con inclusión de jefes y oficiales, para sufrir la misma suerte los que resıltaron elegidos. Ilustración Española y Americana, núm. XXXII (1874), pág. 499.

25 BOzAL, V., Op. cit., págs. 225-239. 


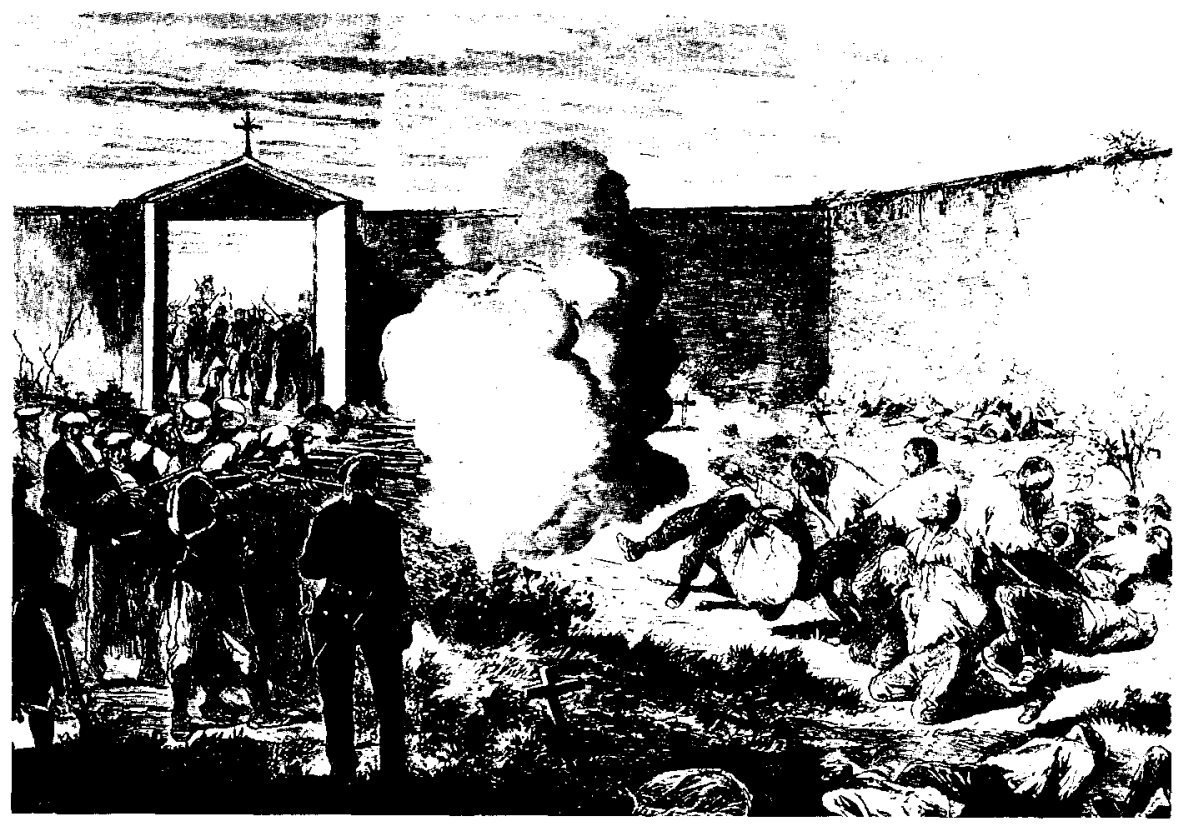

Fig. 11. PEREA, Daniel, Fusilamientos de prisioneros de la columna Nouvilas en el cementerio de Llayés el 17 de julio. La llustración Española y Americana, 30 de agosto de 1874

los escasos segundos de una descarga de fusilería, reflejados en la imagen dinámica de la caída de las víctimas y en el respiandor de la humareda -blanca como la figura del hombre de brazos en cruz del «3 de Mayo»En el cuadro de Goya, la frialdad de lo simbólico transpira en el anonimato del pelotón de soldados, cuyos rostros nos oculta el artista; por el contrario, el dibujo de Perea, aunque de trazo extremadamente simple, acerca y abre el grupo de ejecutores al espectador, que puede en cierta manera identificarles. Una serie de motivos dramatiza, no obstante, el realismo documental de Perea: la contraposición de la terrible mirada de las víctimas con la presencia relajada de sus verdugos; la humillación de las ataduras en las manos; las cruces salpicadas entre los grupos de cadáveres por los que discurre el pelotón en su macabra tarea; y la continua entrada de prisioneros, al amanecer, a un cementerio que nos recuerda la tapia a la que asoman los curiosos en "La ejecución de Maximiliano».

El grabado de la Vsemirnaia Illiustratsiia de San Petersburgo del 8 de noviembre de 1875, "la matanza de los prisioneros carlistas cerca de Benasque en Aragón" (fig. 12), es una copia galvanoplástica del Graphic de 
16 de octubre, un dibujo de Godofrey Durand basado en un boceto realizado in situ por Barrington Kennett. Hay aquí también un recurso compositivo, el farol que ilumina la escena, que recuerda los "Fusilamientos" de Goya. Durand, sin embargo, utiliza el violento claro-oscuro del foco de luz para ocultar en las sombras el rostro de los ejecutados, en contraposición a las escenas de Goya y Perea. Este es, de hecho, sólo un matiz de un elemento más profundo que singulariza fundamentalmente la estampa de Graphic y Vsemirnaia. Perea, como Goya, no pudo ocultar una fuerte empatía con la tragedia sufrida por sus conciudadanos, lo que se refleja en la atmósfera dramática de sus imágenes. En el dibujo de Kennett y Durand, por el contrario, el alejamiento del primer plano de los fusilados, aunque no llega al distanciamiento emocional del cuadro de Manet, reduce la tensión de la escena.

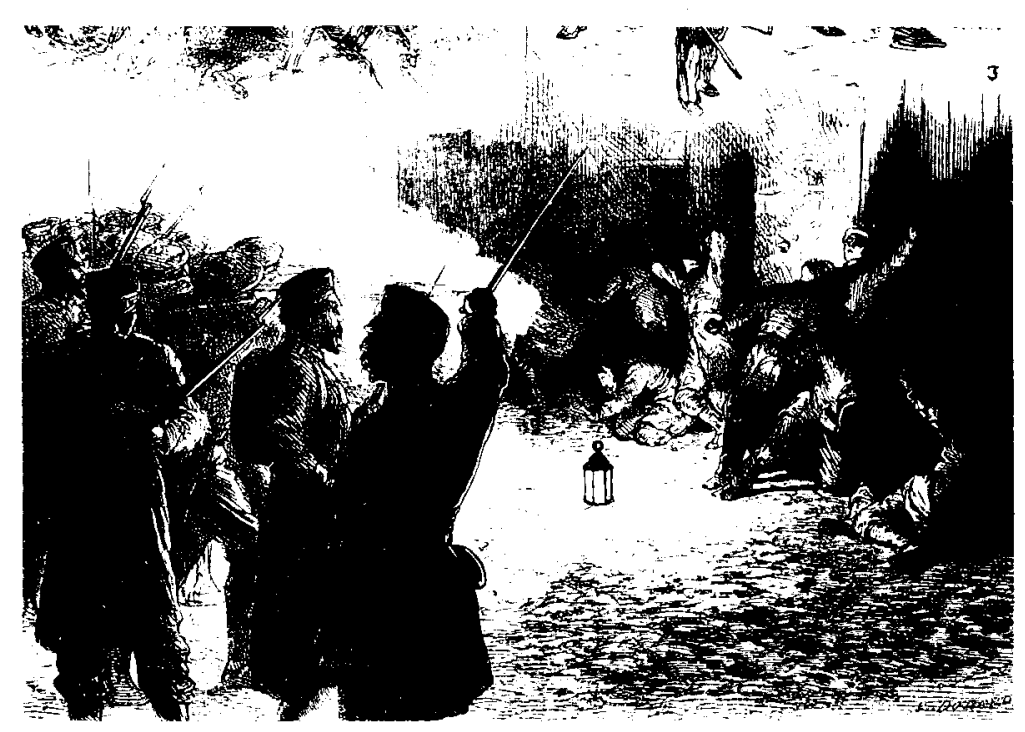

Fig. 12. DuRAND, Godotrey, La matanza de los prisioneros carlistas cerca de Benasque en Aragón. Vsemirnaia liliustratsiia, 8 de noviembre de 1875.

La estampa "Horrores de la guerra" de J.L. Pellicer, publicada el 8 de junio de 1876 en La llustración Española y Americana (fig. 13), es otra muestra de la influencia de Goya, ya manifiesta en el tema - una descripción de víctimas de la guerra-, que es un motivo presente en toda la serie de los Desastres, como señala V. Bozal ${ }^{26}$. Hay, desde luego, otros

Op. cit., pág. 196. 
argumentos en favor de tal influencia. El mismo título, muy goyesco, de la estampa; su publicación tardía, meses después del final del conflicto, lo que pudo permitir a Pellicer una lenta elaboración del dibujo que dejase aflorar toda su formación artística; y la composición misma, un escorzo de muertos muy similar al Desastre 18 («Enterrar y callar»).

La estampa de Pellicer exhibe, no obstante, ciertos rasgos característicos de la ilustración de actualidad. Hay, primeramente, una especial diferencia con el Desastre en cuanto al marco espacial de ambas escenas. En el Desastre, el fondo de la imagen ofrece una intencionada sensación desoladora de vacio y niebla, sin rasgo diferencial alguno en el suelo sobre el que descansan los cadáveres, o en el cielo sobre el que destacan las figuras que los Iloran; por el contrario, la estampa de Pellicer registra cuidadosamente el entorno - piedras, matojos, arbustos- en el que se inscribe el horror de las figuras en escorzo. Obsérvese a este respecto la insistencia de Pellicer en el rótulo, "dibujo del natural», que figura en la leyenda. No sería lícito desestimar la importancia de ese rótulo. Como

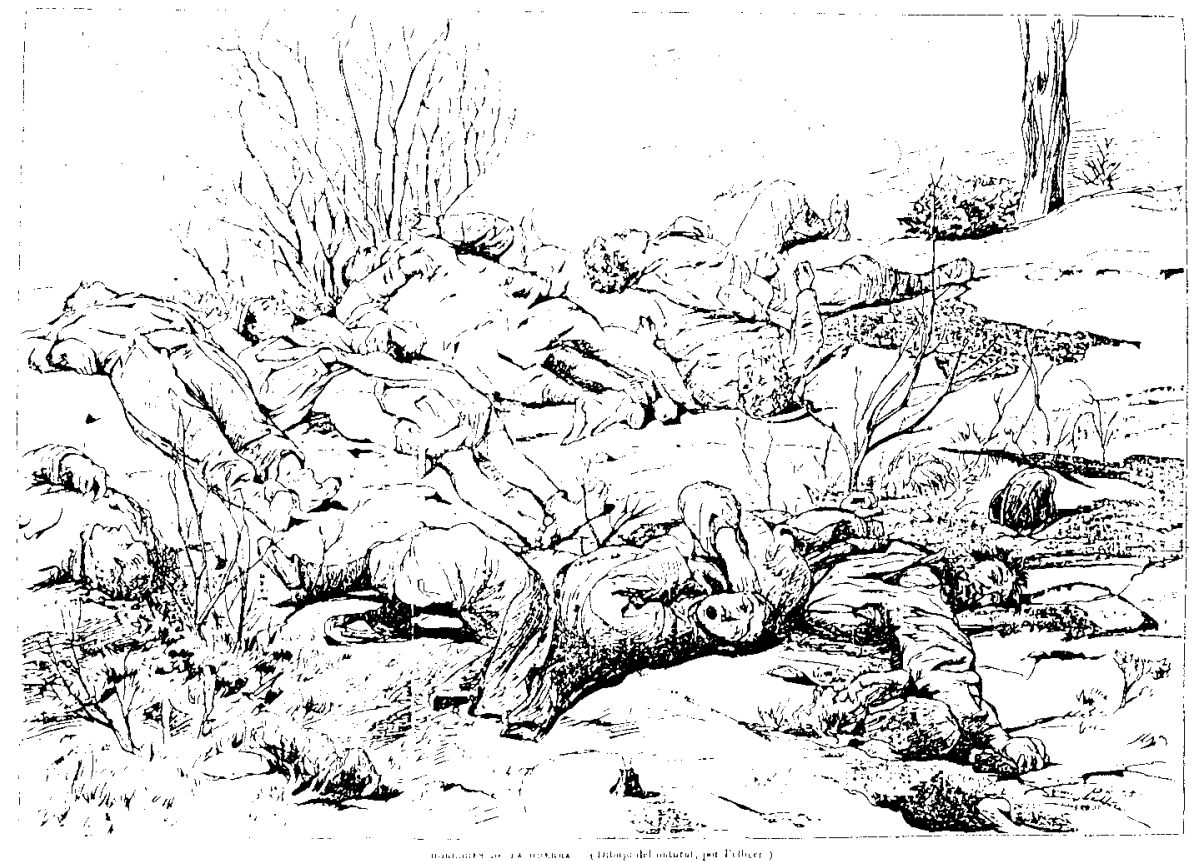

Fig. 13. Pellicer, J.L., Horrores de la guerra. La llustración Espanola y Americana, 8 de marzo de 1876. 
ya se ha documentado, Pellicer, por una parte, fue un artista obsesionado por el dibujo del natural y, por otra, se preocupó en grado extremo de que sus croquis o dibujos no sufrieran modificaciones en estudio antes de llegar al taller de grabación del semanario ${ }^{27}$. Finalmente, es de notar la evidente apariencia de croquis que ofrece el dibujo, muy semejante en el acabado a numerosas estampas que publicó el artista durante la guerra, estampas aparecidas en la revista inmediatamente después de ocurrir los acontecimientos registrados en ellas. En cualquier caso, es notable la congruencia simbólica entre la tardía publicación de los "Horrores de la guerra" y su persistente contenido (los muertos no tienen prisa...), en oposición a la urgente publicación de las escenas de Treviño y Llayés, en cuya carga iconográfica, como ya se ha señalado, primaba la captación inmediata del instante.

${ }^{27}$ BASTIDA, M. Dolores, "José Luis Pellicer, corresponsal artístico en la última guerra carlista", Espacio, Tiempo y Forma, Serie VII, núm. 2, (1989), págs. 343-376. 
